\title{
On-line Learning: Suatu Paradigma Baru dalamPembelajaran Matematika
}

\author{
Dasa Mustakim \\ SMP Negeri 2 Karanganyar Ngawi \\ dasamustakim7109@gmail.com
}

\begin{abstract}
Abstrak
Sejalan dengan berkembangnya inovasi bidang teknologi, pembelajaran melalui komputer dapat terakses ke internet. Pembelajaran seperti ini disebut pembelajaran berbasis web (on-line learning) atau biasa dikenal dengan istilah e-learning. Sistem on-line learning merupakan bentuk implementasi pembelajaran yang memanfaatkan teknologi dan tidak dibatasi oleh ruang dan waktu. Pemanfaatan teknologi tersebut selain sebagai upaya mengatasi permasalahan teknis pembelajaran, juga sebagai upaya menjawab masalah substansial pembelajaran yang dituntut dalam perubahan paradigma pembelajaran. Perubahan paradigma tersebut yakni pengembangan diri peserta didik secara mandiri serta tuntutan kreativitas dan dinamika ilmu pengetahuan. Melalui kegiatan on-line learning, peserta didik dapat berkomunikasi dengan gurunya atau di antara peserta didik sendiri kapan saja dan dimana saja, yaitu melalui e-mail atau fasilitas lainnya. Permasalahan teknis yang dihadapi online learning matematika adalah terdapatnya kesulitan ketika harus menggunakan simbol matematika dalam berkomunikasi.
\end{abstract}

Kata kunci: teknologi informasi, internet, dan on-line learning.

\section{PENDAHULUAN}

Dalam menyongsong kebutuhan masa depan, peserta didik dituntut agar memiliki kemampuan dasar matematika yang handal. Peserta didik diarahkan untuk menggunakan prinsip-prinsip matematika saat memecahkan permasalahan secara kontekstual dalam kehidupan sehari-hari. Hal itu berkaitan dengan fungsi pembelajaran matematika sebagai pembentuk life skill disamping fungsi genuine matematika sebagai induk ilmu pengetahuan.Guna peraihan fungsi praktis maupun fungsi genuine pada masa globalisasi seperti sekarang ini, perlu adanya suatu percepatan dalam proses pembelajaran matematika karena pembaharuan informasi seringkali terjadi begitu cepatnya. Dengan adanya suatu percepatan, pembelajaran peserta didik dapat lebih termotivasi dalam belajarnya, serta mempunyai wawasan ke arah masa depan yang lebih luas. Dalam konteks percepatan, peran teknologi sangat dibutuhkan. Hal ini sesuai dengan pendapat Supriadi (2002) bahwa pada setiap perkembangannya, teknologi selalu bersinggungan dengan pendidikan karena ada kebutuhan dari pendidikan untuk senantiasa meningkatkan efektivitas dan efisiensi dalam pembelajaran dan pengelolaan sistem pendidikan. Tawaran yang diberikan teknologi menjanjikan cara-cara baru untuk mencapai tujuan-tujuan pendidikan/pengajaran secara lebih efektif dan efisien. 
Penerapan teknologi dalam proses pembelajaran merupakan ruang lingkup teknologi pendidikan. Teknologi pendidikan sudah dikenal dalam dunia pendidikan selama ini, antara lain untuk alat-alat bantu belajar seperti slide, OHP, LCD projector, komputer, dan penggunaan alat-alat teknologi lain untuk laboratorium. Sejalan dengan berkembangnya inovasi bidang teknologi, pembelajaran melalui komputer dapat terakses ke internet. Pembelajaran seperti ini biasa disebut pembelajaran berbasis web atau on-line learning.

Internet atau international networking adalah salah satu turunan teknologi informasi yang dapat dimanfaatkan oleh Lembaga Pendidikan Tenaga Kependidikan (LPTK). Internet memiliki karakteristik menjadi media yang menghubungkan masyarakat dunia dari berbagai belahan untuk saling berkomunikasi satu sama lain. Dari sisi teknis, jaringan teknologi jutaan komputer tersebut berimplikasi luas pada berbagai kepentingan pengembangan wawasan peserta didik. Peradaban internet telah membuka pintu untuk lahirnya perpustakaan dunia dengan tingkat efisiensi dan efektivitas yang tinggi. Selain itu, sarana e-mail atau electronic mail yang secara teknis mulai digulirkan tahun 1985 mendorong komunitas pendidikan untuk memanfaatkan terjalinnya komunikasi antara peserta didik dengan sesamanya maupun antara peserta didik dengan tenaga pendidik secara lebih efisien dan efektif.

Kajian ini difokuskan pada paradigma baru melalui percepatan proses pembelajaran matematika dengan rumusan masalah: Pembelajaran bagaimana yang dapat mempercepat proses pembelajaran matematika pada era teknologi informasi ini?
Tujuan penulisan artikel ini adalah mengkaji suatu model pembelajaran yang berbasis internet yang berpeluang untuk dapat mempercepat proses pembelajaran matematika.

\section{Kajian Pustaka dan Pembahasan}

\section{Internet dan On-line Learning (E- Learning)}

Pemanfaatan sarana internet dan $e$ mail untuk kepentingan pembelajaran berpotensi besar dapat diterapkan di Indonesia. Dalam satu dasa warsa terakhir infrastruktur mulai berkembang. Hal ini ditandai dengan meningkatnya jumlah pelanggan dan pengguna internet dalam jumlah yang cukup berarti. Hal ini dapat terlihat pada diagram berikut:

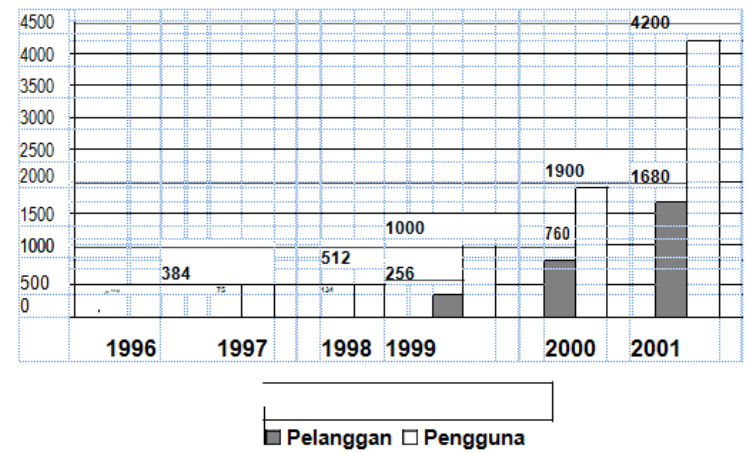

Sumber: Wahana Komputer. 2003. Promosi Efektif dengan Web.

Gambar 1: Perkembangan Pelanggan dan Pengguna Internet di Indonesia (dalam ribuan)

Sarana internet sebenarnya dapat mengatasi masalah struktural pendidikan di Indonesia. Keterbatasan dana dan fasilitas pendidikan serta disparitas mutu pendidikan dapat diatasi oleh sistem pembelajaran nonkonvensional yang berbasis internet. Pembelajaran berbasis internet (on-line learning) biasa dinamakan dengan istilah $e$ - 
learning. Sistem e-learning merupakan bentuk implementasi pembelajaran yang memanfaatkan teknologi dan tidak dibatasi oleh ruang dan waktu. Dengan arti pembelajaran ini dapat dilakukan baik dengan synchronous maupun asynchronous, dilakukan dengan mengoptimalkan peran media elektronik seperti internet, intranet, ekstranet, CD-ROM, video tape, DVD, TV, handphone, PDA, dan lain-lain. Synchronous adalah pembelajaran yang dilakukan dalam waktu yang sama, sedangkan asynchronous adalah pembelajaran yang dilakukan dalam waktu yang berbeda. Banyak pakar pendidikan memberikan definisi mengenai $e$ learning, seperti yang dipaparkan oleh Thompson et al. (2000) bahwa "E-learning is instructional content or learning experiences delivered or enabled by electronic technology". Kemudian Thompson juga menyebutkan kelebihan e-learning yang dapat memberikan fleksibilitas, interaktivitas, kecepatan, dan visualisasi melalui berbagai kelebihan dari masing-masing teknologi.

E-learning menggunakan sistem jaringan elektronik (Local Area Network/ LAN, Wide Area Network/WAN, atau Internet) untuk penyampaian materi ajar, interaksi, ataupun evaluasi pembelajaran. Internet, Intranet, satelit, tape audio/video, TV interaktif, dan CD-ROM adalah media elektronik yang dimaksudkan dalam sistem jaringan ini. Dengan sistem jaringan ini pula e-learning dapat menghubungkan siswa dengan sumber belajarnya (database, pakar/guru, perpustakaan) yang secara fisik terpisah atau bahkan berjauhan. Dalam berbagai literatur, e-learning didefinisikan sebagai berikut: "e-learning is a generic term for all technologically supported learning using an array of teaching and learning tools as phone bridging, audio and videotapes, teleconferencing, satellite transmissions, and the more recognized web-based training or computer aided instruction also commonly referred to as online courses (Soekartawi, 2004).

Dengan demikian, e-learning atau pembelajaran dengan online adalah pembelajaran yang pelaksanaannya didukung oleh jasa elektronik seperti telepon, audio, videotape, transmisi satellite, atau komputer. Berbagai istilah digunakan untuk mengemukakan pendapat/gagasan tentang pembelajaran elektronik, antara lain on-line learning, internet-enabled learning, virtual learning, atau web-based learning. Dalam hal ini kita memerlukan kejelasan tentang kegiatan belajar yang bagaimanakah yang dapat dikatakan sebagai e-learning? Apakah seseorang yang menggunakan komputer dalam kegiatan belajarnya dan melakukan akses berbagai informasi (materi pembelajaran) dari Internet dapat dikatakan telah melakukan e-learning? Untuk menjawab pertanyaan tersebut, ilustrasi berikut ini mungkin akan dapat membantu memperjelas pengertian tentang e-learning (Newsletter of ODLQC dalam Siahaan, 2003).

Misalkan ada seseorang yang membawa laptop ke sebuah tempat yang jauh terpencil. Kemudian dia menggunakan laptopnya dan melakukan akses terhadap materi program pelatihan yang tersedia, tetapi tidak ada layanan bantuan belajar dari tutor maupun dukungan layanan belajar bentuk 
lainnya. Orang tersebut tidak melaksanakan e-learning, karena dia dalam kegiatan pembelajarannya tidak memperoleh layanan bantuan belajar. Jika dia menggunakan telepon genggam dan dapat menghubungi tutor, maka dia melaksanakan e-learning.

Dari ilustrasi tersebut di atas, setidaktidaknya dapat diambil tiga hal penting sebagai persyaratan kegiatan belajar elektronik (e-learning), yaitu (a) kegiatan pembelajaran dilakukan melalui pemanfaatan jaringan (jaringan dalam uraian ini dibatasi pada penggunaan internet) yang dapat saja dengan LAN atau WAN; (b) tersedianya dukungan layanan belajar yang dapat dimanfaatkan oleh peserta belajar, misalnya CD-ROM atau bahan cetak; dan (c) tersedianya dukungan layanan tutor yang dapat membantu peserta belajar apabila mengalami kesulitan.

Disamping ketiga persyaratan tersebut di atas, masih dapat ditambahkan persyaratan lainnya, seperti adanya (a) lembaga yang menyelenggarakan/mengelola kegiatan pembelajaran; (b) sikap positif dari peserta didik dan tenaga kependidikan terhadap teknologi komputer dan internet; (c) rancangan sistem pembelajaran yang dapat dipelajari/diketahui oleh setiap peserta belajar; (d) sistem evaluasi terhadap kemajuan atau perkembangan belajar peserta belajar; dan (e) mekanisme umpan balik yang dikembangkan oleh lembaga penyelenggara.

Pembelajaran elektronik (e-learning) merupakan kegiatan pembelajaran yang memanfaatkan jaringan (Internet, LAN, WAN) sebagai metode penyampaian, interaksi, dan fasilitasi serta didukung oleh berbagai bentuk layanan belajar lainnya (Brown dan Feasey dalam Siahaan, 2003) yang dapat dilakukan dengan metode synchronous ataupun asychronous. Pakar pendidikan lain memberi definisi mengenai e-learning yang tidak begitu jauh dengan definisi di atas, seperti yang dipaparkan oleh Thompson (dalam Cute et al., 1999) berikut ini: "E-learning is instructional content or learning experiences delivered or enabled by electronic technology". Kemudian Thompson juga menyebutkan kelebihan e-learning yang dapat memberikan fleksibilitas, interaktivitas, kecepatan, dan visualisasi melalui berbagai kelebihan dari masing-masing teknologi. Kemudian Abidin dan Nawi (2002) : menyatakan bahwa e-learning merupakan pembelajaran yang menggunakan sistem online sebagai medium perantaraan di antara pengajar dan pelajar. Belajar melalui online ini akan memudahkan kedua-belah pihak, karena penyampaian materi ajar lebih cepat, mudah dan lebih efisien dibanding dengan cara-cara yang lain.

Kartasasmita (2003) mengemukakan bahwa salah satu arti istilah e-learning adalah adanya pembelajaran dengan kombinasi teknologi dan berbagai terapan praktis, serta dengan kesegeraan kemudahan akses ke sumber belajar, ke pengajar, dan ke sesama pembelajar melalui internet. Fakta adanya kombinasi teknologi dengan terapan dalam $e$ learning juga dikemukakan oleh Savel (dalam Kartasasmita, 2004) yang menyatakan bahwa e-learning mengintegrasikan teknologi elektronik dan pendidikan. Oleh sebab itu penggunaan internet sangat dominan pada e-learning. Masih sejalan dengan hal di atas, menurut Linde (2004) $e$ learning adalah pembelajaran baik secara formal maupun informal yang dilakukan melalui media elektronik, seperti internet, 
intranet, CDROM, video tape, DVD, TV, handphone, PDA, dll.

Berdasarkan beberapa pendapat para ahli di atas tersirat bahwa e-learning lebih luas dibandingkan dengan on-line learning yang biasa disebut juga dengan istilah virtual learning. Virtual learning hanya menggunakan internet atau intranet LAN/WAN, tidak termasuk menggunakan CD-ROM. Untuk lebih jelas dapat dilihat pada Gambar 2 berikut.

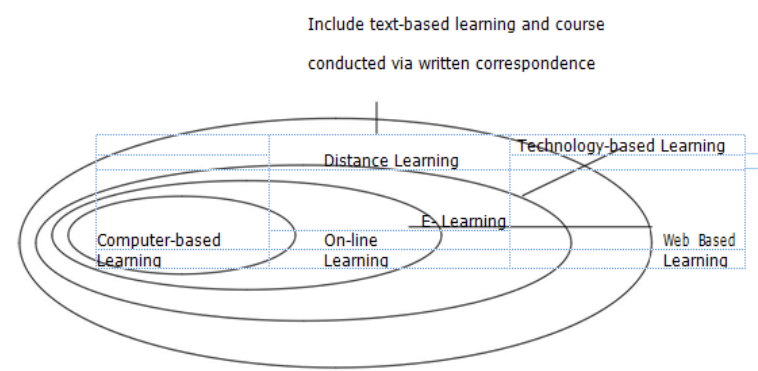

Sumber: WR Hambrecht + Co, http://www.wrhambracht.com__(Simamora, 2003)

\section{Gambar 2: Terminologi Learning bPemanfaatan On-line Learning}

Pemanfaatan teknologi dalam pembelajaran memberi penguatan terhadap pola perubahan paradigma pembelajaran dari pencapaian perolehan tingkat pengetahuan dan keterampilan yang konstan setelah selesai mengikuti pendidikan menjadi pencapaian pengetahuan dan keterampilan yang selalu dapat diperbaharui dalam waktu singkat. Di Amerika Serikat sejak tahun 1996 telah dicanangkan visi penggunaan teknologi yang efisien dari jenjang pendidikan dasar dan menengah dalam rangka mempersiapkan generasi mendatang menjadi generasi yang dapat menjawab tantangan persaingan perekonomian dunia dengan program "Getting America's Students Ready for the $21^{\text {st }}$ Century: Meeting the Technology Literacy Challenge" (Office of Educational Technology, 2001).

Beberapa negara sudah mulai memanfaatkan teknologi, khususnya teknologi informasi dalam proses pembelajaran melalui e-learning.

Pemanfaatan tersebut selain sebagai upaya mengatasi permasalahan teknis pembelajaran, juga sebagai upaya menjawab masalah substansial pembelajaran yang dituntut dalam perubahan paradigma pembelajaran, yakni pengembangan diri peserta didik secara mandiri serta tuntutan kreativitas dan dinamika ilmu pengetahuan. Melalui kegiatan e-learning, peserta didik dapat berkomunikasi dengan gurunya atau di antara peserta didik sendiri kapan saja dan dimana saja melalui e-mail. Selain itu, para peserta didik dimungkinkan untuk tetap dapat belajar sekalipun tidak hadir secara fisik di dalam kelas. Kegiatan belajar menjadi sangat fleksibel karena dapat disesuaikan dengan ketersediaan waktu para peserta didik/peserta didik dengan sumber belajar yang tersedia dan dapat diakses dari internet.

$$
\text { Pada dasarnya e-learning }
$$
mengandung pengertian dan memberikan dampak perluasan peran, cakrawala, dan jangkauan dalam proses pembelajaran bagi para peserta didik. Akan tetapi sejauh ini berdasarkan hasil survei awal, hanya 30\% saja mahasiswa LPTK yang mengetahui mengenai e-learning. Yang mengetahui itupun belum tentu mengoperasionalkan internet. Alasan utama mereka adalah jauhnya sarana warung internet (warnet) dari tempat tinggalnya serta mahalnya biaya 
operasional. Sebagian besar dari mahasiswa yang ditanyai lebih senang memanfaatkan kantin atau perpustakaan sebagai tempat pengisi waktu saat menunggu perkuliahan. Padahal dari mahasiswa yang telah mencoba menelusuri bahan ajar dengan internet, mereka berpendapat hal itu sebagai pengalaman yang menyenangkan. Bahkan sebagian besar responden yang ditanyai yakin bahwa wawasan mereka akan bertambah bila secara intensif memanfaatkan sarana internet dalam pembelajarannya. Dengan demikian, sesungguhnya e-learning cukup berpotensi dalam pembelajaran.

Lembaga Pendidikan Tenaga Kependidikan (LPTK) yang bertanggung jawab melahirkan tenaga kependidikan profesional seyogyanya menjadi pihak yang paling proaktif menanggapi perubahan paradigma pembelajaran, sekaligus kecenderungan mengembangkan penerapan teknologi informasi dalam pembelajaran. Harus diakui bahwa pemanfaatan teknologi akan berkaitan erat dengan pembiayaan pendidikan. Oleh sebab itu pelaksanaannya bisa dilakukan secara bertahap atau dalam bentuk pilihan-pilihan.

Berdasarkan hasil studi, sebagian besar dosen matematika di LPTK cenderung masih menggunakan metode belajar konvensional. Alasan utamanya adalah keterbatasan sarana belajar berbasis teknologi yang dimiliki oleh lembaga. Serta diakui pula adanya keterbatasan penguasaan teknologi informasi sebagai prasyarat dalam mengembangkan model pembelajaran. Penggunaan metode pembelajaran konvensional menurut responden sangat berdampak pada pencapaian penguasaan daya matematis yang optimal di kalangan mahasiswa. Ketergantungan yang tinggi kepada pengajar dalam metode pembelajaran konvensional menyebabkan inisiatif belajar tidak berkembang di kalangan mahasiswa. Saat pengajar tidak dapat menemui mahasiswa di kelas, saat itu pula waktu belajar tidak efektif karena mahasiswa tidak memiliki alternatif kegiatan lain yang dapat meningkatkan daya matematisnya. Boleh jadi fenomena itu yang memungkinkan matematika belum menjadi mata pelajaran yang paling menyenangkan bagi para peserta didik dewasa ini.

Berdasarkan hasil penelitian (Yaniawati, 2006), kendala atau permasalahan teknis yang dihadapi e-leaning matematika adalah saat mengadakan komunikasi tentang materi pelajaran yang membutuhkan penjelasan menggunakan simbol-simbol matematika. Hal ini masih dirasakan kurang praktis dan terdapat kesulitan karena dalam fasilitas-fasilitas $e$ learning yang ada saat ini belum ada fasilitas untuk penggunaan simbol matematika. Jadi komunikasi mengenai materi matematika yang banyak menggunakan simbol matematika belum dapat berlangsung secara optimal. Walaupun demikian, di luar penggunaan simbol, penyelenggaraan $e$ leaning matematika dapat berlangsung secara baik, di antaranya dalam pelaksanaan quiz yang menggunakan feedback. Peserta didik sangat termotivasi dengan sistem quiz semacam melalui e-learning karena mereka dapat mengetahui langsung hasil jawaban mereka saat itu.

Permasalahan teknis pembelajaran diikuti pula oleh lemahnya dukungan infrastruktur. Akibat lemahnya dukungan infrastruktur tersebut menyebabkan 
pemanfaatan e-learning di Indonesia masih tertinggal bila dibandingkan dengan negaranegara tetangga seperti Malaysia, Thailand, Philipina, dan Singapura. Hal ini bisa dilihat dari data pengguna internet dimana pengguna internet terbesar adalah berada di negaranegara maju. Karena berbagai keterbatasan sarana pendukung ini, perkembangan internet di Indonesia belum seperti yang diharapkan. Warung Informasi dan Teknologi atau WARINTEK (Information Technology Kiosk) yang diselenggarakan oleh Kantor Menteri Negara Riset dan Teknologi dan PDII-LIPI baru dimulai tahun 2000 dan kini tumbuh dan berkembang dengan pesat (Soekartawi, 2003). Daya dukung perangkat hukum juga terasa masih lemah. Belum tersosialisasikannya substansi hak intelektual kepada masyarakat luas menyebabkan lemahnya rangsangan pada kelompok pendidik untuk meluncurkan karya-karya ajar melalui saluran elektronik.

\section{SIMPULAN DAN SARAN}

Dalam perubahan paradigma baru pembelajaran, on-line learning (e-learning) berpeluang dapat mempercepat proses pembelajaran matematika. Selain itu, pembelajaran ini dapat meningkatkan motivasi belajar peserta didik karena pembelajaran ini relatif masih merupakan hal yang baru (novelty). Namun demikian, masih terdapat beberapa kendala dalam implementasi pembelajaran ini, terutama permasalahan teknis pembelajaran matematika. Untuk itu, dalam pengimplementasian e-learning, diperlukan perencanaan yang matang baik dalam segi materi ataupun teknisnya. Terdapat empat hal yang perlu disiapkan dalam penyelenggaraan pembelajaran dengan model e-learning sebagaimana dikemukakan oleh Soekartawi (2003), yakni:

a) Melakukan penyesuaian kurikulum. Kurikulum sifatnya holistik, dimana pengetahuan, keterampilan, dan nilai (values) diintegrasikan dengan kebutuhan di era informasi ini. Kurikulumnya bersifat competencybased curriculum;

b) Melakukan variasi cara mengajar untuk mencapai dasar kompetensi yang ingin dicapai dengan bantuan komputer;

c) Melakukan penilaian dengan memanfaatkan teknologi yang ada (menggunakan komputer, online assessment system); dan

d) Menyediakan materi pembelajaran seperti buku, komputer, multimedia, studio, dll yang memadai. Materi pembelajaran yang disimpan di komputer dapat diakses dengan mudah, baik oleh guru maupun peserta didik.

\section{DAFTAR PUSTAKA}

Abidin, A. dan Nawi, R. (2002). E-learning: Penerokaan Media Pembelajaran Terkini. E-learning Unit. Universiti Malaysia Sarawak.

Cute, A. et al. (1999). Handbook of Distance Learning. The McGraw-Hill.

Kartasasmita, B. (2003). Catatan Pengembangan e-learning dalam Budaya Belajar Kini. Makalah Seminar pada tanggal 8 Desember 2003 di ITB Bandung.

Kartasasmita, B. (2004). Berkenalan dengan e-Learning. Makalah Seminar pada 
tanggal 10 Agustus 2004 di UPI Bandung.

Linde, E. (2004). Online Teaching and Learning. Makalah Seminar pada tanggal 16 Februari 2004 di Unpad Bandung.

Office of Educational Technology. (2001). A

Retrospective on Twenty Years of Education Technology Policy. [Online].

www.nationaledtechplan.org/ participate/20years.pdf.

Siahaan, S. (2003). E-learning (Pembelajaran Elektronik) Sebagai Salah Satu Alternatif Kegiatan Pembelajaran. Jurnal Pendidikan dan Kebudayaan. No. 042. Tahun Ke-9. Mei 2003. Jakarta: Universitas Terbuka.

Soekartawi. (2003). E-learning di Indonesia dan Prospeknya di Masa Mendatang. Makalah disampaikan pada Seminar Nasional E-learning Perlu E-Library' di Universitas Kristen Petra Surabaya. [Online].

Http://Incuvl.petra.ac.id/indonesia/ bimbing/elearning2.pdf.

Soekartawi. (2004). Beberapa Kesulitan dalam Pelaksanaan Pembelajaran Berbasis Web pada Sistem Pendidikan Jarak Jauh. Dalam PUSTEKKOM (2004). Teknologi Pembelajaran. Jakarta: PUSTEKKOM.

Supriadi, D. (2002). Internet Masuk Sekolah: Pemberdayaan Guru dan Mahasiswa dalam Era sekolah Berbasis Elearning. Makalah pada Seminar Implementasi E-learning untuk Sekolah Menengah, PT Telkom Bandung.
Thompson, et al. (2000). Perspective in Quality Online Education. [Online]. http:// www.sloanc.org/publications/view/v2n7/pdf.

Wahana Komputer. (2003). Promosi Efektif dengan Web. Yogyakarta: Andi

Wildavsky, B. (2001). Want More from High School? Special Report: E-learning. [Online]. http:/www.usnews/edu/elearning/artic les.

Yaniawati, R. P. (2006). Implementasi ELearning dalam Upaya Mengembangkan Daya Matematik (Mathematical Power) Mahasiswa Calon Guru. Disertasi PPS UPI Bandung: Tidak dipublikasikan. 